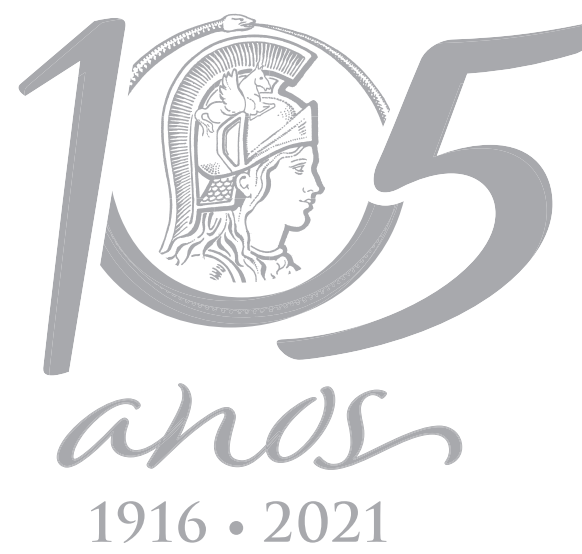

\title{
ECOSYSTEMS
}

\section{Artisanal fisheries of native spiny lobster Panulirus meripurpuratus and smoothtail spiny lobster Panulirus laevicauda in the northeast region of Brazil}

\author{
CARLOS E.R.D. ALENCAR, PAULO V. DO N. ARAÚJO, LARA C. AMORIM, \\ MAURO S.P. LIMA, LIANA DE F. MENDES \& FÚLVIO A. DE M. FREIRE
}

\begin{abstract}
Spiny lobsters (Family Palinuridae) are a popular seafood in Brazil. We characterize the fishing activity and analyze the population of lobster species captured in the coast of the state of Rio Grande do Norte, Northeast Brazil. We monitored the landings of lobster fishermen at the start of the fishing season, from May 24 to November 21, in 2010, at Pirangi beach, the main landing point in the metropolitan area of Natal. The lobster fisherman in the region use small vessels and a compressor to dive in artificial reefs known as marambaias. The artisanal fishermen are engaged in several illegal practices and revealed a greater capture of lobsters categorized as small-sized for the market (11-13.95 cm tail length). The capture area led to different fishing pressures for each species. For P. laevicauda, fishing pressure occurred for all size classes, while for P. meripurpuratus, pressure occurred partially, only for a few population cohorts. On regional scale, fishing involved a demand-supply trade balance centered on the size of capture vs. abundance, regardless of the natural interespecific differences on body size and the preferential distribution area. Our results provide key information for future decision making involving the fishing of spiny lobster.
\end{abstract}

Key words: Fishery activity, fishing technology, fisheries ecology, Palinuridae.

\section{INTRODUCTION}

Spiny lobsters (Decapoda, Palinuridae) are one of the most popular fishery resources in the world (Giraldes \& Smyth 2016). More than 50 years ago, Brazil started to regulate the fishing of spiny lobsters (Madrid \& Izquierdo 2013). In the 1960s, lobster fishing acquired industrial proportions leading to a fall in production over the following two decades. Artisanal fishing for export was encouraged by the Brazilian government and the fishing industry in several coastal regions (Dias-Neto 2008). Lobster is one of the main items of the Brazilian balance of trade and the vast majority of landings are exported, totaling US\$84,082,390.00 in 2010 (Dias-Neto 2008, Oliveira et al. 2015, MDIC 2018).

High consumption and high prices in the international market together with poor management have increased fishing pressure to inappropriate levels and caused the natural stocks of lobster to decrease gradually in each annual cycle (Igarashi 2007). Despite the lobster fishing regulations on the Brazilian coast noncompliance with these norms is threatening the species (Santana et al. 2016).

Lobster artisanal fishing requires the use of different types of traps, some of which comply with the laws, such as cage traps, fishing gillnets and artificial reefs (Madrid \& Izquierdo 2013). 
In many regions of Brazil, fishing frequency and effort are still unknown. Thus, the impact of artisanal fishing on the lobster population for each species is still unclear. Moreover, the last official fishery statistics were published in 2010 (Dias-Neto 2017), which only increases the uncertainty management regarding the studies of lobster populations in Brazil.

Historically, research on lobsters in Brazil focuses primarily on their biological parameters (Ivo 2000, Silva et al. 2008, Cruz et al. 2013, Oliveira et al. 2015, Giraldes \& Smyth 2016), effort control and fishery management (Ivo et al. 1995, Carvalho et al. 1996, Cavalcante \& Furtado-Neto 2012, Santana et al. 2015), fishery production (Ivo \& Ribeiro-Neto 1996a, Fonteles-Filho 2000, Duarte et al. 2010, 2011, Ivo et al. 2013, Madrid \& Izquierdo 2013, Lima \& Andrade 2017), and on lobster farming (Igarashi et al. 2000, Igarashi 2007). These studies provide key information for the regulation of these lobster fisheries. However, we can highlight only a few studies that address the coast of the state of Rio Grande do Norte, such as a biometric research by Vasconcelos \& Vasconcelos (1994) and a study on the monitoring of stationary lift net fishing (Ivo \& Ribeiro-Neto 1996b).

Dias-Neto (2017) assessed the Management Plan for the Sustainable Use of Lobsters in Brazil (Plano de Gestão para o Uso Sustentável de Lagostas no Brasil) and stressed how economic power affects the management criteria of this resource, the limited incentives to monitor the population of the spiny lobster species, and the need to conduct updated ecological studies and studies on the exploitation status of lobsters. Native spiny lobsters (Panulirus meripurpuratus) and smoothtail spiny lobsters (Panulirus laevicauda) are the most marketed species in Brazilian commercial fisheries (Panulirus meripurpuratus sensu P. argus in Dias-Neto 2008, Santana et al. 2016), mainly in the North and Northeast regions, despite efforts of the academic community to create awareness regarding overexploitation since the late 1960s (Igarashi et al. 2000).

The re-evaluation and description of the red lobster Panulirus meripurpuratus (Giraldes \& Smyth 2016) in 2016 as a new species for the Brazilian coast invalidates a lot of information on the population ecology of the former taxon P. argus, which does not occur in Brazil. The reevaluated species $P$. meripurpuratus is native and endemic to the Brazilian coast and it can be found at several depths from shallow to $50 \mathrm{~m}$, mostly between $41 \mathrm{~m}$ to $50 \mathrm{~m}$ (Giraldes \& Smyth 2016). The smoothtail spiny lobster, P. laevicauda, is distributed throughout the Western Atlantic and occurs closer to the coast, at depths of around 30m and 40m (Melo 1999). Both species share similar geographical distributions and can be found in reefs, rocks, and seagrass banks. The new scenario calls for baseline studies on the population parameter and stock conditions of this new taxon in Brazil.

The present study aims to characterize the fishing activity and analyze the population of the spiny lobsters by an artisanal fishing fleet along the east coast of Rio Grande do Norte, the Brazilian state with the second largest production of lobster. In addition, we analyze the population structure of native spiny lobster Panulirus meripurpuratus and smoothtail spiny lobster, P. laevicauda, with data collected on arrival of the fishing fleet. Such data are key to establish measures that improve the management of this fishing resource on Northeast Brazil.

\section{MATERIALS AND METHODS}

\section{Research site}

Fishing data were collected on arrival of the lobster vessels on the east coast of the state of Rio Grande do Norte, Brazil, at the fishing port 


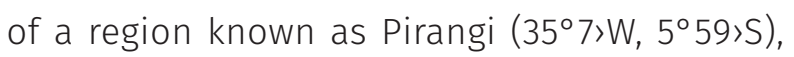
located about $20 \mathrm{~km}$ south of the metropolitan region of the state capital, Natal (Figure 1).

In the region of Pirangi, sandstone reefs can be found from the beach line to the edge of the continental shelf at about $30 \mathrm{~km}$. This region is subject to tide variation and exhibits a partially immersed reef during low tide (Amaral 2006). In addition, bodies of reef, also of sandstone base, are located far from the coast ( 1 to $5 \mathrm{~km}$ from the coast), with varied depth (10m to $50 \mathrm{~m}$ ). Currently, this region is the target of scientific research and environmental awareness projects geared toward creating a marine protected area, mainly due to the richness of its biodiversity and the need to organize use of the marine area to preserve natural resources (Oceânica 2020).

\section{Fishery and vessel data collection}

Data were collected between May to November 2010, during the lobster fishing season. We interviewed fishermen and middlemen to obtain the following information: (a) type of fishing and equipment used, (b) average time of the fishing trip, (c) number of fishermen involved and their functions, (d) costs and payment of fishermen, and (e) most visited sites for lobster fishing. The vessels used for fishing lobsters were characterized and categorized based on whether or not they had been licensed by IBAMA (Brazilian Institute of the Environment and Renewable Natural Resources). Vessels were described according to their size, hull material, motor power (HP), and storage of the lobsters on board, as suggested by Carvalho et al. (1996).

\section{Data collection on arrival of vessels}

For each month, a subsample of 2000 specimens was previously determined to analyze population structure. When the total catch fell below the threshold of the subsample, all the individuals were sampled. Therefore, once vessels arrived

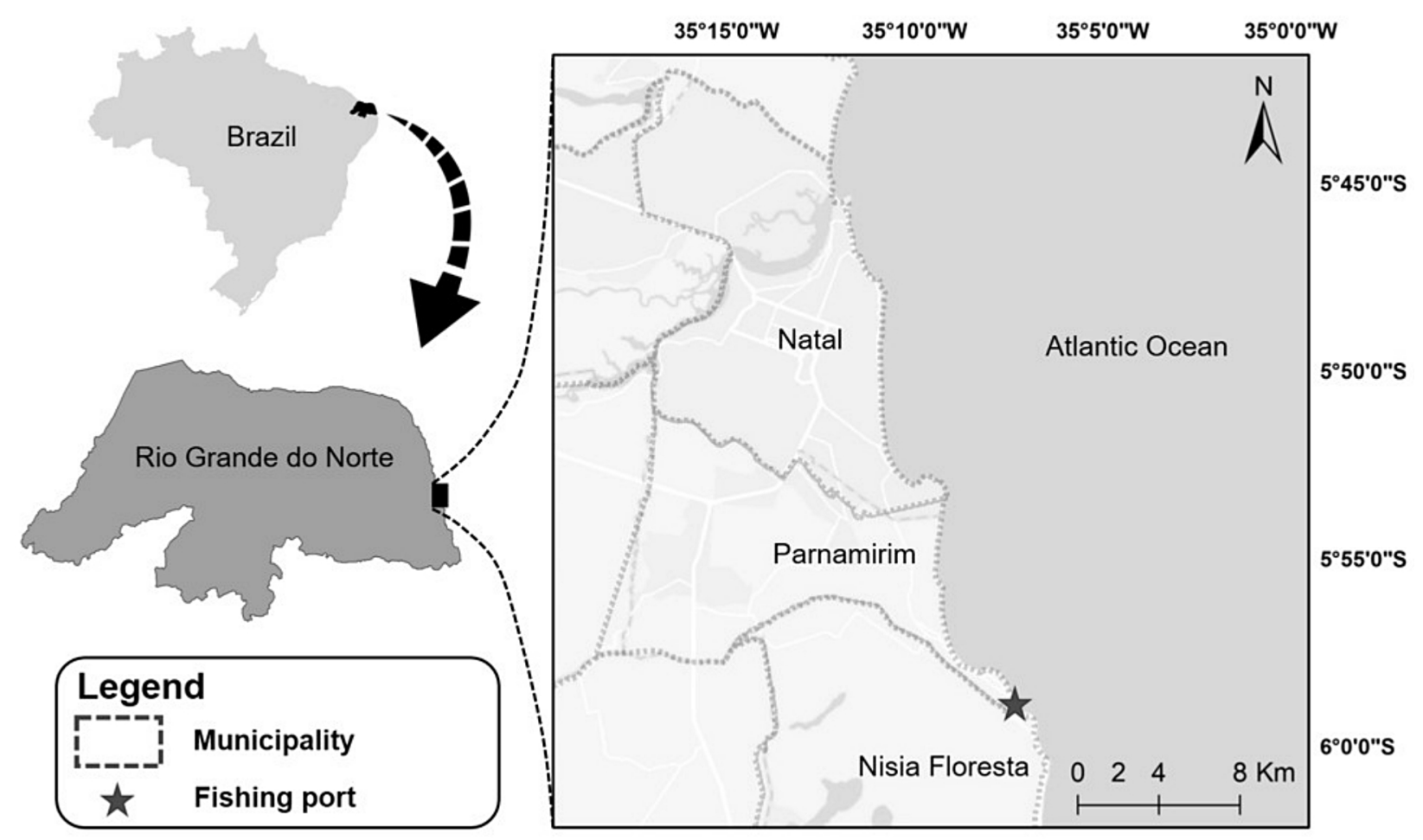

Figure 1. Study area and sampling site of lobster Panulirus spp. on the eastern coast of Rio Grande do Norte. 
at the landing site and the subsample was depicted we measured the tail of each specimen and recorded its sex. In May, lobsters were identified and accounted for, but not sexed. In June, however, about $50 \%$ of them were sexed. Due to logistical issues with the fishermen who handle and allocate lobsters, it was not possible to record the sex of all the specimens in May and June of 2010.

We measured the tail length (TAL) of each specimen using a $0.5 \mathrm{~cm}$ precision caliper ruler, between the anterior edge of the first abdominal segment and the tip of the telson (Ivo et al. 1995), while the specimen was laid flat on a surface. Sex was identified by observing external sexual features, namely simple pleopods for males and double pleopods for females (Coelho 1962a, b). Ovigerous females were identified through the presence of eggs in the ventral portion of the abdomen.

Lobster production was assessed considering the count (abundance) of tails by species and sex, according to the sales per size categorization used by the middlemen and fishermen: (a) "large lobsters"; specimens with tail length over $14 \mathrm{~cm}$, (b) "small lobsters"; tail length between 11 and $13.95 \mathrm{~cm}$, and (c) "tiny lobsters"; tail length under $11 \mathrm{~cm}$ for $P$. laevicauda and under $12 \mathrm{~cm}$ for P. meripurpuratus. Finally, we estimated relative count of tails based on occurrence of length categories at intervals of $1 \mathrm{~cm}$ for each species, and $2 \mathrm{~cm}$ for the sex assessment.

\section{Statistical analysis}

Tail length (TAL) values were initially tested for normality and homogeneity of variance using the Shapiro-Wilk (Shapiro \& Wilk 1965) and Levene tests (Zar 2010). A Kruskal-Wallis test (Hollander \& Wolfe 1973) was conducted to compare mean TAL values according to month, species, and sex, followed by a Dunn post-hoc to compare paired ranks (Dunn 1964). In the post-hoc test, the $p$ value was adjusted using the "BH" method of Benjamini \& Hochberg (1995). Skewness and kurtosis measures of distribution data for TAL category were determined for each species and sex, and then submitted to the KolmogorovSmirnov test for two samples (Conover 1971). This test verifies whether the two datasets to be assessed have the same distribution according to the characteristics of position (skewness) and height (kurtosis) of the data distribution curve (Zar 2010).

The proportions of population categories for each species were analyzed separately considering time (months) and sales commercial category, using multinomial proportion tests (Goodman 1964).

Then, we conducted a correspondence analysis (CA) to assess the proportions of population categories together against the fishermen's sales commercial category considering length. CA is a statistical method that shows associations among contingency table levels. The associations found for the two variables (population categories per species and fishermen length categories) are summarized by the frequency of each cell in the table and then placed in a three-dimensional geometric space, so that the positions of each row and column are consistent with the associations of the table (Nenadic \& Greenacre 2007). This procedure results in a broad and interpretable view of the multivariate data. Significant CA axes, which corresponded to a cumulative variation greater than $80 \%$, were considered. In addition, we performed a permutation test $(n=999)$ to compute a probabilistic value of significance $(p)$ for the observed associations. Graphic points related to the fishermen's length categories were proportionally inserted according to their abundance of the contingency table, generating a clear visualization of the 
association/abundance of each length group and the population categories per species.

Only data from June to November 2010 were used for statistical analysis. All analyses were performed using the R software (R Development Core Team 2009) with the aid of the "ca" package (correspondence analysis; Nenadic \& Greenacre 2007), "stats" (Kruskal-Wallis test; R Development Core Team 2009), and "PMCMR" (post-hoc test of Dunn; Pohlert 2016). In all analyses, we established a significance level of 5\% (Zar 2010).

\section{RESULTS}

\section{Characterization of fishing activities}

During the study period, 16 vessels used for fishing of lobsters were registered in the beach of Pirangi, among which only 5 were licensed. Thus, about $70 \%$ of the vessels did not have permission to catch lobsters.

Lobster vessels in this region were defined as small, considering they had wooden hulls between $7 \mathrm{~m}$ and $12 \mathrm{~m}$ long (Figure 2a). The lobsters were stored on the deck of the vessel, on ice in Styrofoam boxes or, less commonly, in the vessel's hold.

Lobsterfishing occurred on daily trips and the catch was landed - only the fresh tails - directly to the middlemen. Lobster cephalothorax was discarded at sea, kept for the fishermen's own consumption, or distributed in the community. Generally, lobster vessels departed for fishing at around 7:00am, and arrived back in the evening at the same location at high tide and on the beach at low tide.

This type of fishing was carried out frequently, varying according to weather conditions and whether the IBAMA inspection speedboat was there or not, since most of the vessels and the fishing gear did not comply with the law. Thus, on days of clear water and with no risk of on-site inspection, the fishermen went

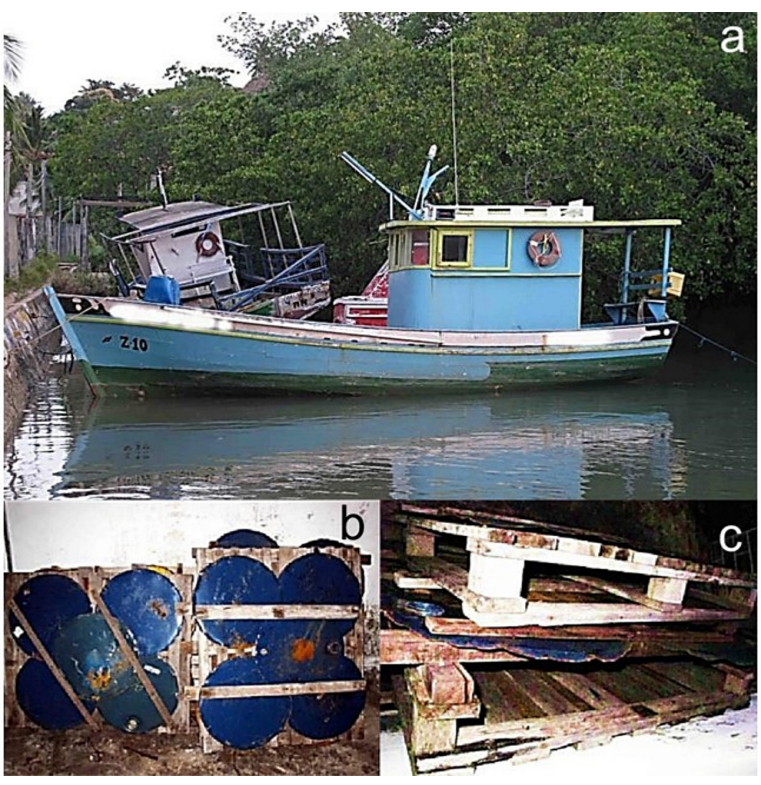

Figure 2. Artisanal fisheries of spiny lobster Panulirus spp. on eastern coast of Rio Grande do Norte. (a) Small vessel used in lobster fisheries in the Pirangi area; (b) Upper and (c) lateral view of the marambaias used to attract spiny lobsters. Photos: Mauro Lima.

on daily trips from Monday to Saturday. When the water was murky and/or inspection agents were seen on-site, few or no vessels went out to fish on any day of the week.

Lobsters were caught mainly using diving compressors, in artificially built fishery sites, popularly known as marambaias or in natural fisheries, known by the fishermen as restinga (when they could not find any more lobsters at the marambaias, due to intense fishing in the first months of the lobster fishing season). An average of 16 and a maximum of 35 marambaias, at around 7.3 meters deep, were observed per day.

The marambaias were made using empty oil barrels purchased from resellers, who get them from chemical plants. The empty oil barrels were hammered and attached to wood pallets. The marambaias were placed in areas known as restingas, which consist of a flatbottom substrate made with gravel (rhodoliths of calcareous algae and tube polychaete). 
These structures provided artificial shelters for lobsters (Figure 2b, c). The fishermen marked the locations of the marambaias with GPS devices so they could return to the same spot and catch the lobsters 1 to 3 months later. Each vessel leader or ship owner had hundreds to thousands of marambaias out at sea to ensure satisfactory production during the fishing season.

The trip from landing site to the first fishing spot took around 2 hours, varying according to the distance of the fisheries and weather condition, especially the speed and direction of the wind. The fishing activity per trip (visiting all marambaias and fisheries in the restingas) lasted on average 5 to 6 hours.

Due to the small size of the vessels, fishing for lobster in Pirangi involved 4 to 5 fishermen, among which two were divers, one was a leader and one or two were mangueristas (persons in charge of loosening the rope and pulling it back, who also went diving when necessary). The leader, usually the oldest of all the men, was in charge of the work on board, including deciding the site, targeting fishing locations, and determining how long these operations would take. The other crew members (fishermen/ divers) were also overseen by the leader.

In the diving activity, compressors were connected to the engine of the boat to inject compressed air into 15 to 20 cylinders. Oxygen reached the divers through a hose. Two other fishermen - the mangueristas or hosemen controlled the valves that regulated pressure and air volume.

The fishing operation was performed aboard the vessel and the divers went down to depths of around 10 to $40 \mathrm{~m}$. A diver checked the marambaias to see if there was a good number of lobsters. If so, he would then signal through the air supply hose to another diver to come down and help catch the lobsters.
While fishing, the diver used a fishing gaff, which they call a bicheiro (a wooden handle of approximately $50 \mathrm{~cm}$ with a sharp metal hook on one end) to remove lobsters from the marambaia and trap the group for later collection with a rede de mangote (gill net). The gill net usually had a 5 to $7 \mathrm{~mm}$ mesh diameter, floats on the upper edge and sinkers on the bottom to keep it open while the lobsters were being caught. Then, a cable was used to pull up the gill net with the lobsters to the surface, so that the hosemen (mangueristas) could collect them on-board the vessel. Each diver went through an average of 8 to 10 marambaias per dive, and would then undergo a procedure of decompression to return to the surface and be replaced by another diver.

After intense fishing activity (2 to 3 months), the marambaias were virtually empty, so they started diving in random areas looking for lobsters in natural grounds, which could be reef areas or on sand bars. On the sand bars, the fishing process was similar to the process used in the marambaias - a fishing gaff was used to drag the lobsters out of their natural shelters and a gill net was used to pull them up to the surface.

Most lobster production was landed at the end of the day to the middlemen and separated according to the categories of commercial sales ("large lobsters", "small lobsters", and "tiny lobsters"). The landings were weighed and stored in Styrofoam coolers with ice. The eggs of ovigerous females were removed with spoons. The middlemen paid each group of fishermen from each vessel on weekends according to their production. Half of the payment was given to the owner of the vessel and the other half was shared between all the fishermen who had participated in the trip. Some vessel owners participated in the fishing activity and they would receive half of the total production in that 
trip, plus their portion of the other half that was shared between the fishermen.

During the research period, the "small lobster" was sold for R\$35.00/kg (around U\$20; dolar quotation 2010: $\mathrm{R} \$ 1,75)$ by the fishermen and resold to the export companies by the middlemen for $\mathrm{R} \$ 45.00 / \mathrm{kg}$ (about U\$26.5). The "large lobster" was sold for $\mathrm{R} \$ 45.00 / \mathrm{kg}$ (about U\$26.5) by the fishermen and resold for $\mathrm{R} \$ 55.00 /$ $\mathrm{kg}$ (about U\$32.4) to the export companies. The "tiny lobsters", those with tail length under the legally permitted length, were shared among the fishermen for their own consumption and partly sold to the middlemen. In the latter case, when much of the production consisted of tiny lobsters, the middlemen would pay $\mathrm{R} \$ 15.00 / \mathrm{kg}$ of tail (about U\$8.82/ kg), which was sold in the local community, especially to tourists, owners of local bars, and restaurants.

The average cost of each fishing trip ranged between $\mathrm{R} \$ 100.00$ (about U\$58.82) and $\mathrm{R} \$ 150.00$ (U\$88.23). Expenses included food and fuel. The ice used to keep lobsters cooled on-board the vessel was provided by the export companies.

\section{Population structure of lobster catches}

Spiny lobster fishing was allowed from May to November in 2010. During this period, 4,230 lobster tails were measured in vessel landings, including $43.40 \%(n=1,836)$ of native spiny lobster Panulirus meripurpuratus and 56.60\% ( $n=2,394)$ of Smoothtail spiny lobster $P$. laevicauda. The latter was the most captured species of lobster in all the months, except November. Both species showed abundance peaks in October (Figure 3a). The distribution of lobster tail length frequency varied from 8 to $30 \mathrm{~cm}$. The $13.5 \mathrm{~cm}$ length category was the most frequent for $P$. meripurpuratus, and the $12.5 \mathrm{~cm}$ category was the most frequent for $P$. laevicauda. The frequency distribution of $P$. laevicauda was similar to a normal distribution; values of central tendency in the symmetrical plan of the curve and the sides (tails) in categories with decreasing values (normal curve, Zar 2010). P. meripurpuratus presented a similar distribution to an asymmetric curve to the right; values of central tendency in the symmetric plane of the left with an abrupt interruption in the higher categories (asymmetric curve, Zar 2010) (Figure 3b).

The Kruskall-Wallis test showed significant differences for tail length in different months for the species and for month vs. species in each test run (Table I). Significant difference were found in most of the comparisons, except for June vs. July and November vs. July. (Table I).

The percentages of ovigerous females caught during this research period were lower compared to males and non-ovigerous females for both species (3.33\% Panulirus meripurpuratus and $14.50 \%$ P. laevicauda). A greater and lesser abundance of ovigerous females of $P$. laevicauda were recorded in October $(n=51)$ and November $(n=7)$, respectively. The ovigerous females of the species $P$. meripurpuratus were more abundant in October $(n=10)$ and least abundant in July ( $n=$ 1). Ovigerous females were less abundant in the catches of $P$. meripurpuratus than $P$. laevicauda. Both species had similar tem poral variability; no occurence in May and in the following months alternating abundance peaks (Figure 3c). The ovigerous females of $P$. meripurpuratus had a greater range-size distribution and catch peak $(17.5 \mathrm{~cm})$ than P. laevicauda $(13.5 \mathrm{~cm})$ (Figure $3 \mathrm{~d}$ ).

Lobster sex ratio was registered in 3,391 individuals; 770 males and 780 females of $P$. meripurpuratus and 917 males and 924 females of P. laevicauda (0.99:1 males:females). As the months passed, the lobster sex ratio varied slightly from 0.75 to 1.17 (males: females) for $P$. meripurpuratus and from 0.77 to 1.14 for $P$. laevicauda (Figure 3e, f). 

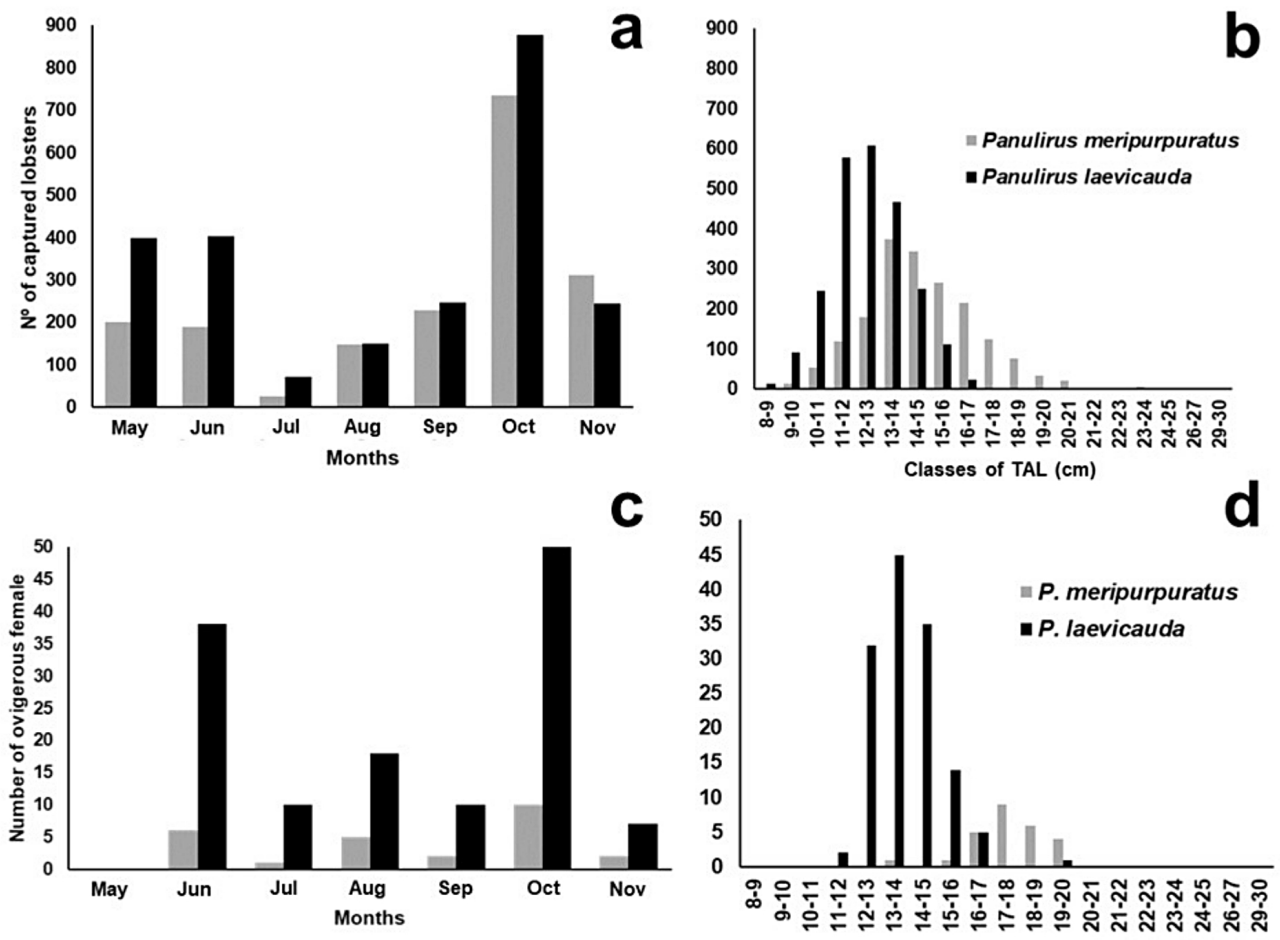

Figure 3. Artisanal

fisheries of spiny lobster Panulirus spp. on eastern coast of Rio Grande do Norte.

(a) Number of lobsters landed during the study months; (b) Number of lobsters landed in size classes of TAL (cm); (c) Number of ovigerous females landed during the study months; (d) Number of ovigerous females landed in classes of TAL (cm);

(e) Frequency of occurrence (\%) of males and females for P. meripurpuratus; (f) Frequency of occurrence (\%) of males and females for

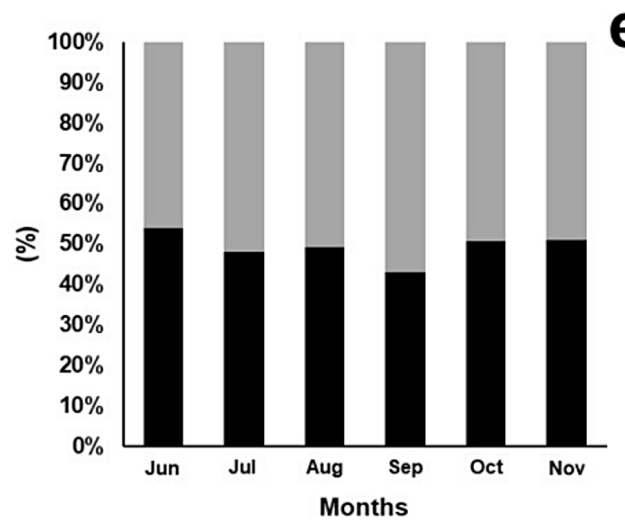

e ${ }_{100}$ Classes of TAL (cm) P. laevicauda. TAL Tail length.

Monthly variation in the size category was similar to that observed when all the data were assessed, with catch peaks in the same size categories, with little variation. However, in these cases, the numerical difference was not so relevant. Throughout the fishing season, we found that the sizes of lobsters decreased for both species with each passing month. Larger P. laevicauda lobsters $(16-18 \mathrm{~cm}$ and $18-$ $20 \mathrm{~cm}$ ) were caught in the initial months of the fishing season, from June to August, while smaller lobsters $(14-16 \mathrm{~cm})$ were caught from
September to November. The same occurred with P. meripurpuratus; lobsters that fit the 15$17 \mathrm{~cm}$ length category were mostly caught in the months of June and July, while from August to November the catching peaks fit the $13-15 \mathrm{~cm}$ category (Figures 4 and 5).

Sex ratio was similar in each month for each species separately (Kolmogorov-Smirnov test, $p>0.05$ ). Exceptionally in October, when the highest number of catches occurred, males were more abundant than females for both species (Figures 4 and 5). 
Table I. Statistical summary from Kruskal-Wallis tests considering tail length as the dependent variable and group factors by Species, Month and Sex analyzed separately. Post-hoc evaluation only performed for the time factor Month; bold values indicate statistical significance $(p<0.05)$.

\begin{tabular}{|c|c|c|c|}
\hline \multicolumn{4}{|c|}{ Kruskal-Wallis test for Tail Lenght } \\
\hline $\begin{array}{l}\text { Source of } \\
\text { variation }\end{array}$ & $\begin{array}{l}\text { Chi- } \\
\text { square }\end{array}$ & $\begin{array}{l}\text { Degree of } \\
\text { freedom }\end{array}$ & $p$ value \\
\hline Species & 856.51 & 1 & $<0.0001$ \\
\hline Month & 318.31 & 5 & $<0.0001$ \\
\hline Sex & 4.0785 & 1 & 0.0434 \\
\hline \multicolumn{4}{|c|}{ post-hoc for Month } \\
\hline \multicolumn{2}{|c|}{ Peer-to-peer comparison } & \multicolumn{2}{|c|}{$p$ value } \\
\hline \multicolumn{2}{|c|}{ July x August } & \multicolumn{2}{|c|}{0.0718} \\
\hline \multicolumn{2}{|c|}{ June $x$ August } & \multicolumn{2}{|c|}{0.1275} \\
\hline \multicolumn{2}{|c|}{ November x August } & \multicolumn{2}{|c|}{0.0662} \\
\hline \multicolumn{2}{|c|}{ October x August } & \multicolumn{2}{|c|}{$<0.0001$} \\
\hline \multicolumn{2}{|c|}{ September x August } & \multicolumn{2}{|c|}{$<0.0001$} \\
\hline \multicolumn{2}{|c|}{ June x July } & \multicolumn{2}{|c|}{0.4509} \\
\hline \multicolumn{2}{|c|}{ November x July } & \multicolumn{2}{|c|}{0.4854} \\
\hline \multicolumn{2}{|c|}{ October x July } & \multicolumn{2}{|c|}{$<0.0001$} \\
\hline \multicolumn{2}{|c|}{ September x July } & \multicolumn{2}{|c|}{0.0064} \\
\hline \multicolumn{2}{|c|}{ November $x$ June } & \multicolumn{2}{|c|}{0.8157} \\
\hline \multicolumn{2}{|c|}{ October x June } & \multicolumn{2}{|c|}{$<0.0001$} \\
\hline \multicolumn{2}{|c|}{ September $x$ June } & \multicolumn{2}{|c|}{$<0.0001$} \\
\hline \multicolumn{2}{|c|}{ October x November } & \multicolumn{2}{|c|}{$<0.0001$} \\
\hline \multicolumn{2}{|c|}{ September x November } & \multicolumn{2}{|c|}{$<0.0001$} \\
\hline \multicolumn{2}{|c|}{ September $\mathrm{x}$ October } & \multicolumn{2}{|c|}{$<0.0001$} \\
\hline
\end{tabular}

Species and sex proportions for the commercial sales categories had similar sex ratios for $P$. laevicauda, for which the "small lobster" category occurred the most. For $P$. meripurpuratus, the greatest amount of lobsters caught fit the "large" category, both for males and females (Table II). Mean vessel landings were mostly represented by the "small" category, with $62.46 \%$ ( $P$. meripurpuratus $=720 ;$ P. laevicauda $=$ 1,398). The "large" category accounted for $23.12 \%$ ( $P$. meripurpuratus $=644 ; P$. laevicauda $=140$ ) and the "tiny" category accounted for $14.42 \%$ ( $P$. meripurpuratus = 186; . laevicauda = 303).

Catches of $P$. meripurpuratus in the different commercial categories were quantitatively more homogeneous throughout the fishing season (Figure 6a). On the other hand, the "small" and "tiny" lobster categories of P. laevicauda were the most abundant (Figure 6b). In October, the month with the largest production of the season, "small" lobsters occurred the most for both species. The smoothtail spiny lobster ( $P$. laevicauda) accounted for $70.00 \%$ of the total "small" lobsters caught, and P. meripurpuratus represented $80.37 \%$ of the total in the "large" category. "Small lobster" catches for $P$. laevicauda showed the highest proportion of landings in all the fishing months (Figure 6b). "Tiny lobsters" were more abundant in October for both species (21.83\% for P. meripurpuratus and $27.19 \%$ for P. laevicauda). No specimen of the species $P$. meripurpuratus categorized as "tiny" was found in the vessel arrivals in June. In July, $1.41 \%$ of "tiny lobsters" of the species P. laevicauda and $98.59 \%$ of $P$. meripurpuratus were registered (Figures $6 \mathrm{a}$ and $6 \mathrm{~b}$ ). Fishing data of the commercial category "large lobster" mostly exhibited specimens (both males and females) of P. meripurpuratus. However, the "small" and "tiny" categories corresponded mostly to specimens (both males and females) of $P$. laevicauda (permutations $=999, X^{2}=559.37$, $p<0.001$; Figure 6c). 

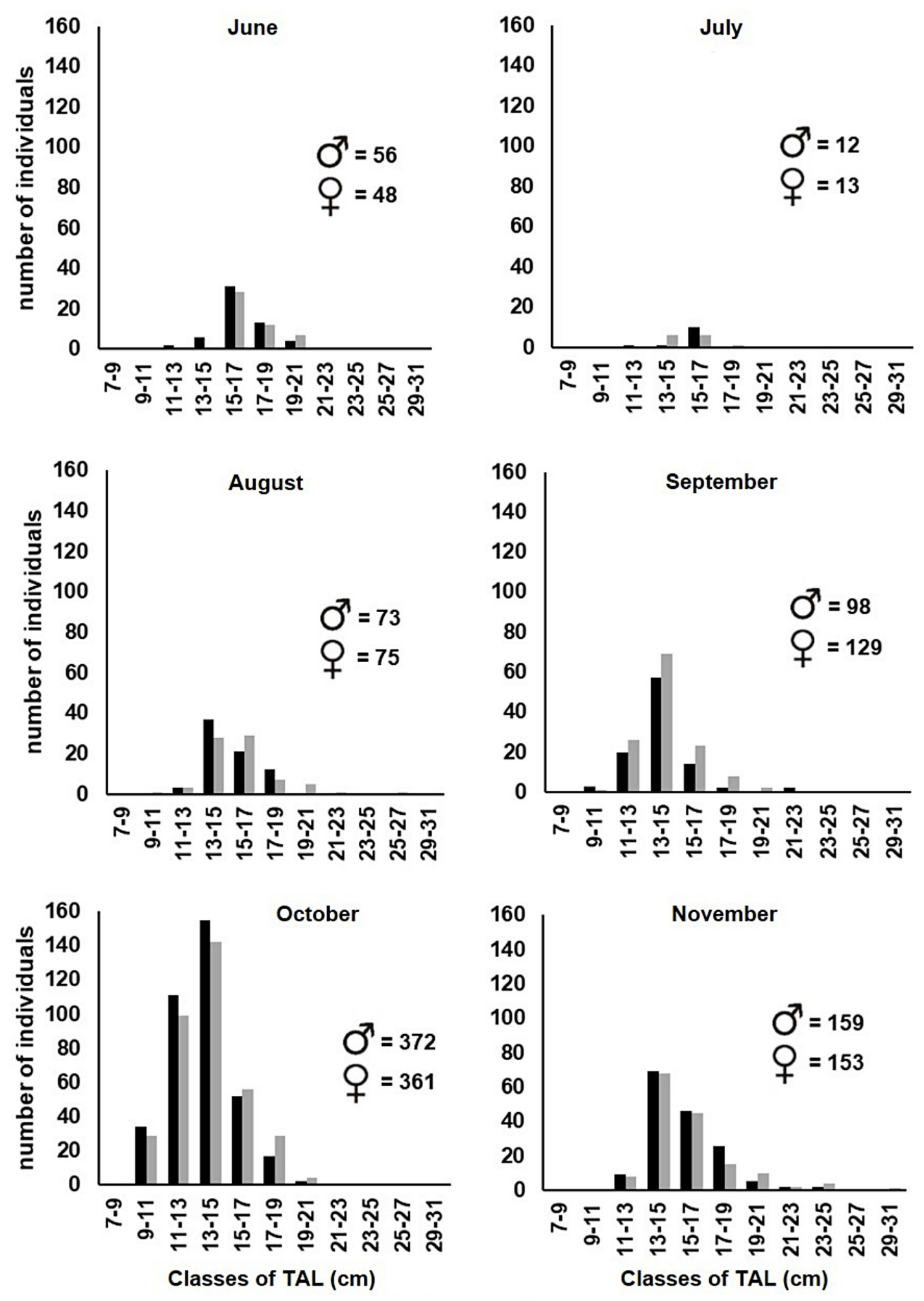

- Males $\quad$ Females

Figure 4. Frequency distribution of tail length classes (TAL), per sampling month and intersexual comparison for the species Panulirus meripurpuratus. 

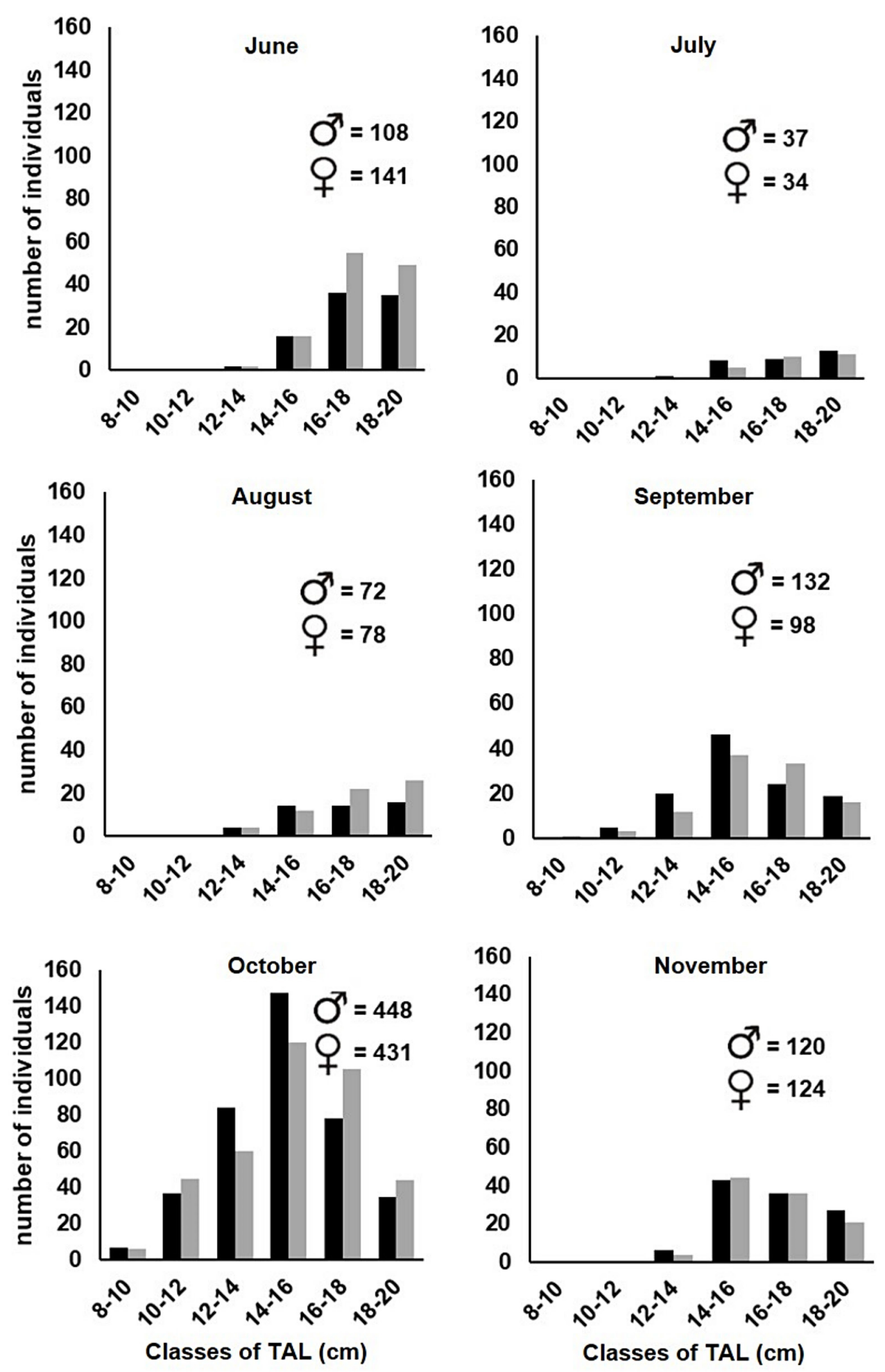

\section{- Males Females}

Figure 5. Frequency distribution of tail length classes (TAL), per sampling month and intersexual comparison for the species Panulirus laevicauda. 
Table II. Multinomial proportions of the species collected, by sex, in the sampling months and according to the regional commercial categories.

\begin{tabular}{|c|c|c|c|c|c|c|c|}
\hline Species / Sex & $\begin{array}{l}\text { sales } \\
\text { categories }\end{array}$ & Jun & Jul & Aug & Sep & Oct & Nov \\
\hline \multirow{3}{*}{$\begin{array}{l}\text { P. meripurpuratus / } \\
\text { males }\end{array}$} & Large & $48 \mathrm{Ab}$ & $10 \mathrm{AC}$ & $41 \mathrm{Ab}$ & $22 \mathrm{BC}$ & $90 \mathrm{Ba}$ & $94 \mathrm{Aa}$ \\
\hline & Small & $8 \mathrm{Bd}$ & $2 \mathrm{Bd}$ & $30 \mathrm{AC}$ & $66 \mathrm{Ab}$ & $193 \mathrm{Aa}$ & $64 \mathrm{Bb}$ \\
\hline & Tiny & 0 & 0 & $2 \mathrm{BC}$ & $10 \mathrm{Bb}$ & $89 \mathrm{Ba}$ & $1 \mathrm{Cc}$ \\
\hline \multirow{3}{*}{$\begin{array}{l}\text { P. meripurpuratus / } \\
\text { females }\end{array}$} & Large & $48 b$ & $9 \mathrm{AC}$ & $50 \mathrm{Ab}$ & $40 \mathrm{Bb}$ & $109 \mathrm{Ba}$ & $83 \mathrm{Aa}$ \\
\hline & Small & 0 & $4 \mathrm{AC}$ & $23 \mathrm{BC}$ & $81 \mathrm{Ab}$ & $181 \mathrm{Aa}$ & $68 \mathrm{Ab}$ \\
\hline & Tiny & 0 & 0 & $2 \mathrm{CC}$ & $9 \mathrm{Cb}$ & $71 \mathrm{Ca}$ & $2 \mathrm{BC}$ \\
\hline \multirow{3}{*}{ P. laevicauda / males } & Large & $4 \mathrm{BC}$ & $1 \mathrm{BC}$ & $16 \mathrm{Bb}$ & $12 \mathrm{Bb}$ & $43 \mathrm{Ca}$ & $5 \mathrm{Bbc}$ \\
\hline & Small & $102 \mathrm{Ab}$ & $35 \mathrm{AC}$ & $52 \mathrm{AC}$ & $95 \mathrm{Ab}$ & $277 \mathrm{Aa}$ & $109 \mathrm{Ab}$ \\
\hline & Tiny & $2 \mathrm{BC}$ & $1 \mathrm{Bd}$ & $4 \mathrm{CC}$ & $25 \mathrm{Bb}$ & $128 \mathrm{Ba}$ & $6 \mathrm{BC}$ \\
\hline \multirow{3}{*}{ P. laevicauda / females } & Large & $8 \mathrm{Bb}$ & $2 \mathrm{BC}$ & $6 \mathrm{Bb}$ & $4 \mathrm{Cbc}$ & $27 \mathrm{Ca}$ & $12 \mathrm{Bb}$ \\
\hline & Small & $131 \mathrm{Ab}$ & $32 \mathrm{Ad}$ & $68 \mathrm{AC}$ & $96 \mathrm{Abc}$ & $293 \mathrm{Aa}$ & $108 \mathrm{Ab}$ \\
\hline & Tiny & $2 \mathrm{BC}$ & 0 & $4 B C$ & 16 Bb & $111 \mathrm{Ba}$ & $4 B C$ \\
\hline
\end{tabular}

Same capital letters represent statistical equality $(p>0.05)$ in the same column (among commercial sales categories). Same lowercase letters represent statistical equality $(p>0.05)$ on the same row (within each sales category for months).

\section{DISCUSSION}

More P. laevicauda were caught compared with P. meripurpuratus, proportionally. Although both species occur in overlapping areas in a large part of the continental shelf (Ivo 2000), P. laevicauda occurs preferably at $40 \mathrm{~m}$ deep (Fonteles-Filho 2000), while $P$. meripurpuratus is more abundant from $41 m$ to $50 m$ (Giraldes \& Smyth 2016).

Tail size patterns observed in this study may indicate the fishing occurrence in shallower areas. Lobsters of both species exhibit a positive relationship between depth and their mean body size (Ivo et al. 1995). We noted that frequency distribution per size category for $P$. meripurpuratus differed from that of $P$. laevicauda.

Ivo (2000) points out that lobster fishing is carried out in shallow waters ( $25 \mathrm{~m})$ using waiting fishing net, such as the gillnet (caçoeira). Because of the narrow and shallow continental shelf in this region (Short \& Klein 2016), lobster fishing occurs from the tide region to depths of 30 to $40 \mathrm{~m}$. In addition, the fishing technology used in the fisheries (mainly marabaias) limits the performance of lobster fishing to the range of $24.5 \mathrm{~m}$. Therefore, the sampled bathymetric amplitude of the lobster vessels covers the distribution of the two species. However, below the true demography abundance range recorded for P. meripurpuratus.

Based on the proportions of capture and different size category trends for each species herein, we conclude some aspects on the population structure considering size/ age (Sparre \& Venema 1997) of the analyzed commercial lobsters on the Rio Grande do Norte east coast. According to this pattern (1) fishing takes place at depths that span the co-occurrence of the two species, each with its peculiarities of abundance and average sizes and (2) the fishing area covers the whole range of bathymetric occurrence and, consequently, of body size, of the population of P. laevicauda. In contrast, (3) 

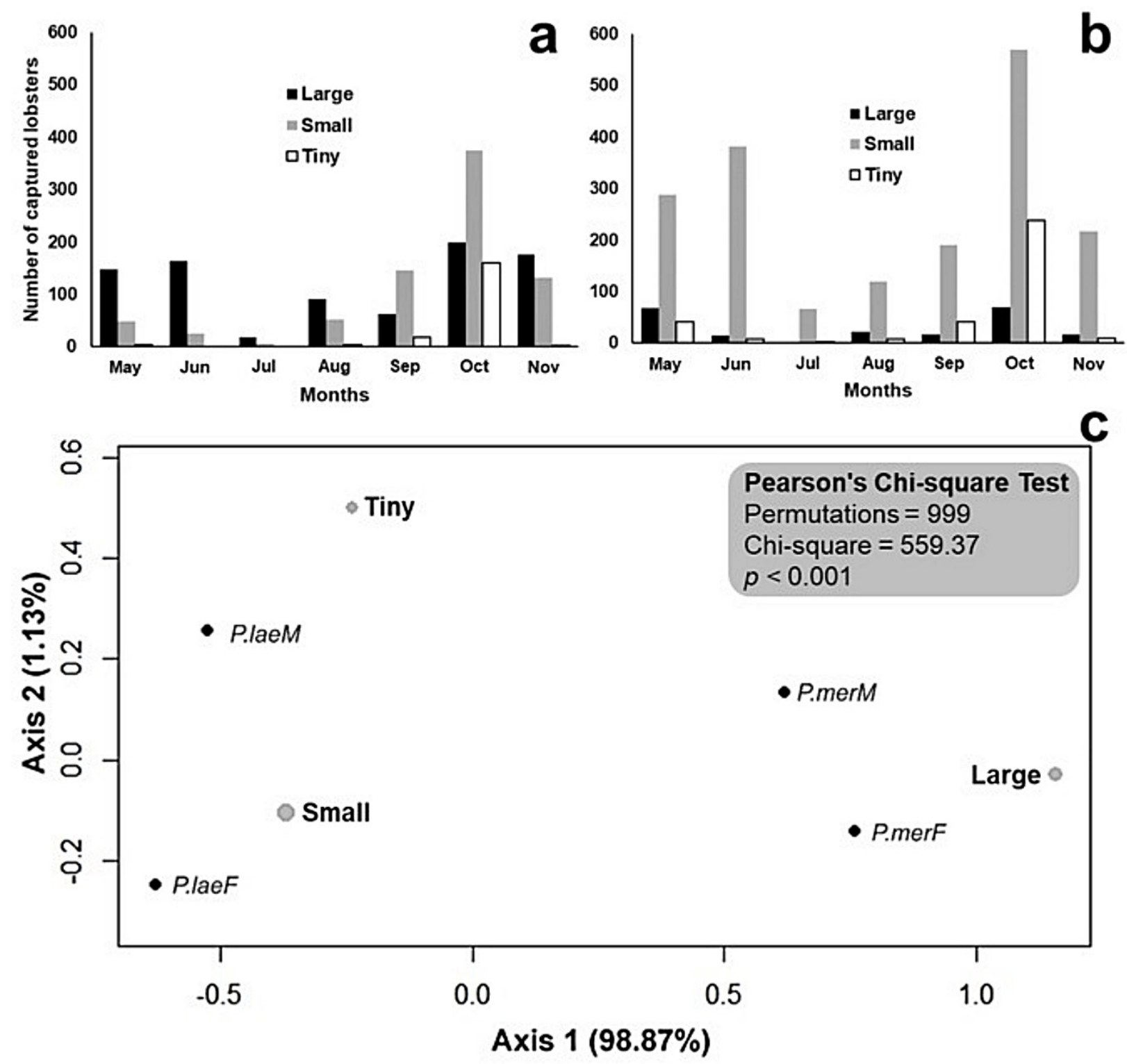

Figure 6. Artisanal fisheries of spiny lobster Panulirus spp. on eastern coast of Rio Grande do Norte by comercial sales categories. (a) Number of lobsters landed in commercial sales categories for P. meripurpuratus; (b) Number of lobsters landed in commercial sales categories for P. laevicauda; (c) Biplot of the correspondence analysis between the capture information according to the commercial sales categories vs. intersexual classification (P.mer - P. meripurpuratus, P.lae - P. laevicauda, M - male, F - female).

this same area does not cover the whole extent of bathymetric occurrence and thus body size structure of the population of P. meripurpuratus (asymmetry to the right). (4) Since the values of abundance do not cover the entire population of $P$. meripurpuratus, these values do not reflect true demography (population underestimate).
Therefore, we suggest that Panulirus spp. stocks on Rio Grande do Norte east coast could be affected if the presented fishing characteristic maintain over.

The impact of lobster fishing is aggravated by the concentration of fishing effort in shallow areas of the continental shelf, a region historically 
known for the greater capture of $P$. laevicauda on the Brazilian coast (Santos \& Ivo 1973, FontelesFilho 1979, 1992). In general, the differences in mean tail length of the species was only $1 \mathrm{~cm}$ $(10 \mathrm{~mm})$. In surveys carried out previously, with collections near the isobath of $25 \mathrm{~m}$, the mean difference between the species was $4 \mathrm{~cm}$ (Ivo et al. 1995, Ivo 2000). In addition, ovigerous females were significantly more abundant and reached a lower midpoint in the size category compared to $P$. meripurpuratus. Finally, the sex ratio for each species separately was 1:1, which agrees with data reported in a previous study in this same region (Ivo et al. 1995).

The results of this study reveal an emerging concern about maintaining lobster stocks for both species. Two significant issues were identified: the first issue addresses the fishing pressure for all age groups and sexes of $P$. laevicauda. Lobsters of smaller sizes are less profitable per unit caught. Therefore, a greater number of small lobsters must be sold to make the same profit that would be made by selling larger lobsters. The second issue refers to the directional fishing pressure against some population cohorts of $P$. meripurpuratus. Larger lobsters generate higher financial yield per unit captured, thus, this fishing activity should be continued even with lower production, in comparison with $P$. laevicauda. In fact, data analyzed from the perspective of commercial size classification revealed a great proportion of $P$. laevicauda landings (higher proportion in the commercial categories "small" and "tiny"), which is more abundant and generates lower income per unit than P. meripurpuratus (higher proportion in the commercial category "large"). Therefore, the fishing scenario shown here reveals a balance of trade centered on the selective supply of lobster in a specific time of the year- larger lobsters are preferred in the initial months of the fishing season. Later, when the larger lobsters start disappearing, the fishermen give priority to small- and mediumsized lobsters. In addition, the local demand favors the sale of "tiny" lobsters at lower prices offered by the middleman, which are then resold for much higher prices to the tourist industry.

Fishing has affected all the size categories of the population of $P$. laevicauda. In the medium and long term, fishing might also affect recruitment and the mean body size of the lobster population (Neves et al. 2013). Reducing a given population attribute - mean body size of the lobster population - may encourage new reproductive strategies to guarantee the survival of the offspring (Stearns 1976). Moreover, reducing the body size of lobsters at sexual maturity can indirectly reduce the fecundity of females. In males, it causes the production of lighter and smaller spermatophores in consecutive mating events, which, in turn, causes lower fertilization of oocytes (Butler et al. 2015). The fishing of $P$. meripurpuratus, on the other hand, showed a higher capture effort in specific population cohorts. Reducing individuals in specific population cohorts may limit the supply of individuals in the population that are capable of breeding. In both cases, lobsters can reach smaller mean body sizes compared to those from populations without fishing pressure. From a commercial perspective, this may involve a lesser financial yield per unit of fisheries and a lower numerical compensation (greater abundance to be captured) thus demanding greater fishing effort. Consequently, high numbers of catches in specific population cohorts may disrupt the maintenance of stocks.

During their life cycle, lobsters form large groups that move short distances daily and randomly, but they also move long distances seasonally in search of suitable areas for breeding (Fonteles-Filho \& Ivo 1980). The fishermen's reports indicate that the 
marambaias are installed in the depth range where there is relevant movement of lobsters. These fishing regions end up becoming shelters for local fish, thus increasing the capture effort per unit of time. Since the vessels occasionally can capture additional fish species as bycatch along with the lobsters. These locations include individuals that move in search of shelter for breeding events, which may justify the occurrence of ovigerous females. The amount of ovigerous females of P. laevicauda in June and October probably depict the two reproductive periods of this species. The first period starts in January and ends in June (or July) and the second occurs in October (Coelho 1962a, b). The capture range of this study favors the capture of non-ovigerous females, considering that the range of preference for the ovigerous females is 40 to 50 meters deep (Fonteles-Filho \& Ivo 1980).

The highest values of tail length for ovigerous females compared to the non-ovigerous females, for both species, shows that the capture of ovigerous females possibly includes females that have already undergone a first sexual maturity. This stage occurs in P. meripurpuratus lobsters with tails of around $13 \mathrm{~cm}$ long and in P. laevicauda lobsters with tails of $11 \mathrm{~cm}$, according to Fonteles-Filho (2005). According to legal norms (Decree n. 138, from December 6, 2006, Brazilian Ministry of the Environment), for the purposes of inspection, the permitted tolerance is up to $2 \%$ of lobster biomass below the minimum permitted size in relation to the total biomass of landed lobsters. This tolerance is only acceptable when the difference in size of the smaller specimen outside the legal range (minimum acceptable size) and the smallest specimen within the legal range does not exceed $2 \mathrm{~mm}$. The same normative statement forbids the fishing of lobsters by means of any kind of diving procedure.
The reduced number of lobsters sampled in July may be related to or justified by the presence of the agency that inspects lobster fishing (IBAMA). IBAMA is mostly active on the east coast of the state during this period. Their performance is essential because there are usually few vessels and the most common practice is by means of diving compressors, which is an illegal activity that deserves effective inspection. It should also be noted that since January 2007, the same decree prohibits the use of marambaias - in any material - as an auxiliary instrument to shelter living aquatic organisms.

On the last months of the fishing season (September and October), the capture of lobsters with tail sizes below the minimum legal size permitted increased, mainly of $P$. meripurpuratus. At the beginning of the fishing season (May), the catches increased regardless of the species and commercial classification.

According to our observations, two possible reasons for the lack of concern regarding the legal minimum size permitted and/or indiscriminate capture of species in the east coast of the state of Rio Grande do Norte are (1) the social class of the fishermen and (2) the supply vs. demand ratio.

Alencar \& Maia (2011), in a study on the socio-economic profile of Brazilian fishermen, concluded that $83.62 \%$ of artisanal fishermen are illiterate or have not finished primary school. For lack of choice, these people are often attracted to the fishing activity, thus adding to the paradigm of fishing and poverty (Alencar \& Maia 2011). The low level of formal education among fishermen is common in Brazil and contributes to their precarious living situation and the permanence of their families and following generations in less favored economic classes (Tamano et al. 2015). Silva (2014) pointed out that artisanal fishermen living in the northeast region are the poorest of Brazil. According to environmental 
analysts, poverty and environmental protection are interdependent realities that need to be understood and addressed as a whole in order to find a more suitable solution (Silva et al. 2014). If environmental degradation exacerbates the living and working conditions of the poorest populations, their poverty leads to the unsustainable exploitation of natural resources and creates a harmful cycle of environmental damage (Lima 1997, Salas et al. 2007).

The now extinct Ministry of Fisheries and Aquaculture ("MPA"), under the influence of the political private sector, since its creation in 2009, took measures that intensified this vicious cycle of resource exploitation and impoverished fishermen. The MPA increased fishing effort above the sustainable limit (40 million creels/ day), reduced fishing licenses for large vessels, and increased allowances for small sailing vessels, when it is known that $84 \%$ of fishing is practiced illegally with the use of gillnets and diving. In addition, it anticipated the opening of lobster fishing season by 11 days, which may have contributed to an increase of approximately 8\% in fishing effort (Dias-Neto 2017).

The second reason may be due to the supply and demand ratio. The commercial aspect is already incorporated into the perception of the fishermen when they sell tails individually. Basically the fishermen differentiate the species by relative body size $-P$. meripurpuratus is identified because its body size is larger than P. laevicauda. The empirical categorization of the species directly affects their sales value by category of sale for export. Thus, fishermen apply such values based on categories and not on relative size (evolutionary allometry, sensu Cock 1966) of the species.

Inappropriate infrastructure for storing, processing, and marketing lobster generates the risk of contamination and depreciation of the price of lobsters (Gonçalves 2011). Such poor conditions force the fishermen to sell their product to middlemen, regardless of supply and demand, for derogatory prices. Apparently, this is a common market practice for the northeast coast of Brazil (Ceara state, Rodrigues \& Maia 2007; Paraiba state, Oliveira et al. 2009). The partnership these fishermen have with the middlemen ensures the necessary input for the fishing, but in the general context of the fishery production chain, it decreases their overall income (Santos et al. 2011).

Furthermore, at the very beginning of this productive chain, they are subjected to high stress due to the high risk of death. When diving with compressors, the risk of an accident increases exponentially with depth, and the slightest error during decompression, either from defective equipment and/or from physical effort, can cause decompression sickness and embolisms. Moreover, the imminent presence of environmental inspectors can further increase the stress factor of divers. Recently, Cavalcante \& Miranda (2015) highlighted the results of an informal study carried out by the regional labor department of the state of Rio Grande do Norte, in which $86.4 \%$ of the diver fishermen have suffered at least one hyperbaric accident as a result of errors during decompression in fishing activities. In addition, two lobster fishing communities - from a total of 32 lobster fishing communities in Rio Grande do Norte - in the period of two years, registered 12 fatal cases of hyperbaric decompression.

Public policies for the national fishing activity, initiated in the second half of the 20th century, have mostly favored the industrial sector. However, they recklessly disregard the balance between economic and ecological aspects that are driving the fishing activity resources to over exploitation (Tursi et al. 2015). This process has mainly harmed artisanal fishermen, who are the weaker link of the productive chain of 
lobsters, by breaking their social relations of production and, consequently, weakening and impoverishing them with scarce and precarious incentives (Costa 2014). In spite of the public policies for managing lobster fishing in Brazil (Madrid \& Izquierdo 2013), the socio-economic condition of artisanal fishermen has never been the reason for investments in the sector. However, some strategies to maintain exports due to economic pressure led to the increased use of marambaias in 2009, which could have caused a drop in production in 2011 and 2012 (Dias-Neto 2017).

The lobster fishery practices examined in the present study depict the patterns of fishing operation and production found in most municipalities with lobster producers in northeastern Brazil. Most of the vessels use illegal methods of fishing, catch lobsters that are smaller than the legally permitted size or that are ovigerous females, and increase the fishing effort at the beginning of the fishing season (R.G. D'Oliveira, unpublished data).

\section{CONCLUSIONS}

The fishing of lobsters on the east coast of the state of Rio Grande do Norte in Brazil is characterized as artisanal fishing with some illegal practices. Among them, the greatest concern is the predominant diving with compressors because it exposes the fishermen to a high risk of death and health issues and it affects lobster stocks. This type of fishing activity can be the most selective and sustainable kind provided the technical standards of safety in diving since the lobsters are selected in an environmental friendly manner. Norms must be improved for this type of demanding work, possibly by determining quotas of capture and ensuring effective inspection. However, in practice, most divers catch all the lobsters they find in the area of the fisheries, including the categories that are legally prohibited (specimens below the minimum size allowed and ovigerous females).

The vessels followed the same trend as observed all over the coast of Rio Grande do Norte (personal communication, CERDA, PVNA), namely small, unlicensed boats with an inadequate infrastructure to store and transport the species caught. Lobster production is marketed through a system of intermediation with middlemen. According to the data collected in this study, such a practice only increases the disorganized fishing activity on the coast, both for the native spiny lobster Panulirus meripurpuratus and for the smoothtail spiny lobster P. laevicauda. In contrast, intermediation is the only supply-demand tool the fishermen have to guarantee their profit and promote the fishing activity.

The most frequently captured category was "small" lobsters, mostly P. laevicauda. The bathymetric depth of capture ranged from 0 to $40 \mathrm{~m}$, preferred by the smoothtail spiny lobster and partially by the native spiny lobster. The use of this bathymetric band for catching lobsters in the medium and long term might create directional variances for each species and both species may suffer population depletion. Temporally, the catches in the initial months indicated larger mean body sizes, while the later months in the fishing season exhibited lobsters with smaller body sizes on average. Such results were expected, considering the time of low fishing (closed season) between December and April. Although small-sized lobsters have registered both for $P$. meripurpuratus and for P. laevicauda, most of the specimens caught exhibited tail sizes permitted by law. 


\section{Acknowledgments}

We thank all the fishermen in Pirangi region who have kindly and voluntarily turn available the information, data and contributed to the knowledge of this fishery. We thank the ONG Oceânica for making this research feasible in partnership with the Federal University of Rio Grande do Norte and Emanuel Dias and João Nascimento Neto for their assistance in the fieldwork. We also thank the anonymous reviewers for the criticism and suggestions in this manuscript. Declaration of interest: None.

\section{REFERENCES}

ALENCAR CAG \& MAIA LP. 2011. Perfil socioeconômico dos pescadores brasileiros. Arq Cienc Mar 44: 12-19.

AMARAL RF. 2006. Diagnóstico dos aspectos geológicos e geomorfológicos da área de Pirambúzios. In: DIAGNÓsTICO AMBIENTAL DA ÁREA DE PIRAMBÚZIOS. Natal: LEGEO, p. 277.

BENJAMINI Y \& HOCHBERG Y. 1995. Controlling the false discovery rate: a practical and powerful approach to multiple testing. J Royal Stat Soc 57: 289-300.

BUTLER MJ, MACDIARMID A \& GNANALINGAM G. 2015. The effect of parental size on spermatophore production, egg quality, fertilization success, and larval characteristics in the Caribbean Spiny lobster, Panulirus argus. ICES J Mar Sci 72(suppl 1): i115-i123. https://doi.org/10.1093/ icesjms/fsv015.

CARVALHO RCA, FERREIRA CRC, VASCONCELOS JA, OLIVEIRA MYS \& CAMPOS LMA. 1996. Custos e rentabilidade de embarcações envolvidas na pesca da lagosta no Nordeste do Brasil, 1995. Bol Téc Cient CEPENE 4: 233-262.

CAVALCANTE ES \& MIRANDA FAN. 2015. The trajectory of the life of artisan fishermen victims of spinal cord injuries caused by diving: experiences, social representations and stress. Online Braz J Nurs 14(suppl.): 463-466. http:// dx.doi.org/10.17665/1676-4285.20155137.

CAVALCANTE PPL \& FURTADO-NETO AMA. 2012. Implementação de quotas individuais transferíveis e do desembarque compulsório de lagosta viva como estratégia de ordenamento da pesca. Arq Cienc Mar 45: 49-59.

COCK AG. 1966. Genetical Aspects of Metrical Growth and Form in Animals. Q Rev Biol 41: 131-190. https://www.jstor. org/stable/2818805.

COELHO PA. 1962a. Súmula de observações da lagosta comum Panulirus argus (Latreille). Bol Inst Pesca 2: 3-11.
COELHO PA. 1962b. Sobre a biologia da pesca da lagosta cabo-verde Panulirus laevicauda (Latreille). Bol Inst Pesca 2: 3-8.

CONOVER JW. 1971. Practical Nonparametric Statistics. J Wiley \& Sons, Nova York, p. 462.

COSTA AA. 2014. Avaliação das políticas públicas de incentivo ao cooperativismo na pesca artesanal: o caso da rede de comercialização solidária de pescado do complexo lagunar Patos-Mirim, Rio Grande do Sul. In: Haimovici M, Andriguetto Flho JM \& Sunye PSA. Pesca marinha e estuarina no Brasil: estudos de caso multidisciplinares. Rio Grande, Editora da FURG, p. 55-63.

CRUZ R, SILVA KCA \& CINTRA IHA. 2013. Assessment of wild lobsters in the continental shelf of Brazil. Crustaceana 86: 336-356. http://dx.doi.org/10.1163/15685403-00003173.

DIAS-NETO J. 2017. Avaliação da execução do plano de gestão para o uso sustentável de lagostas no Brasil. Brasília: IBAMA. p. 64. Retrieved April 21, 2018, from http:// www.ibama.gov.br/phocadownload/biodiversidade/ biodiversidade-aquatica/gestao-pesqueira/ publicacoes/2017-avaliacao-da-execucao-do-plano-degestao-lagostas.pdf.

DIAS-NETO J. 2008. Plano de gestão para o uso sustentável de Lagostas no Brasil: Panulirus argus (Latreille, 1804) e Panulirus laevicauda (Latreille, 1817). Brasília: IBAMA. p. 121. Retrieved April 20, 2018, from http://www.ibama. gov.br/phocadownload/biodiversidade/ biodiversidadeaquatica/gestao-pesqueira/publicacoes/2008-livroplano-gestao-uso-sustentavel-lagostas.pdf.

DUARTE LFA, SEVERINO-RODRIGUES E \& GASALLA MA. 2010. Slipper lobster (Crustacea, Decapoda, Scyllaridae) fisheries offthe southeastern coast of Brazil: I. Exploitation patterns between $23^{\circ} 00^{\prime}$ and $29^{\circ} 65^{\prime}$ S. Fish Res 102: 141 151. https://doi.org/10.1016/j.fishres.2009.11.004.

DUARTE LFA, SEVERINO-RODRIGUES E \& GASALLA MLA. 2011. Contextualização da pesca mundial de lagostas e características de comercialização de Scyllarides spp. e Panulirus spp. na Baixada Santista, Estado de São Paulo, Brasil. Bol Inst Pesca 37: 235-246. ftp://ftp.sp.gov. br/ftppesca/37_3_235-246.pdf.

DUNN OJ. 1964. Multiple comparisons using rank sums. Technometrics 6: 241-252. http://dx.doi. org/10.2307/1266041.

FONTELES-FILHO AA. 1979. Biologia pesqueira e dinâmica populacional da lagosta Panulirus laevicauda (Latreille), no Nordeste setentrional do Brasil. Arq Cienc Mar 19(12): 1-43. 
FONTELES-FILHO AA. 1992. Population dynamics of spiny lobsters (Crustacea: Palinuridae) in northeast Brazil. Cienc Cult 44: 192-196.

FONTELES-FILHO AA. 2000. The state of the lobster fishery in northeast Brazil. In: Phillips BF, Kittaka J. Spiny lobsters: fisheries and culture. Blackwell, Oxford, p. 121-134.

FONTELES-FILHO AA. 2005. Síntese sobre distribuição, abundância, potencial pesqueiro e biologia lagostavermelha Panulirus argus (Latreille) e a lagosta-verde Panulirus laevicauda (Latreille) do Nordeste do Brasil. Relatório de Avaliação do Potencial Sustentável de Recursos Vivos na Zona Econômica Exclusiva MMA REVIZEE. Análise/Refinamento dos Dados Pretéritos Sobre Prospecção Pesqueira. Fortaleza-CE, LABOMAR. Retrieved June 15, 2018, from http://www.mma.gov.br/ estruturas/revizee/_arquivos/sinlagos.pdf.

FONTELES-FILHO AA \& IVO CTC. 1980. Migratory behaviour of the spiny lobster Panulirus argus (Latreille), off Ceará State, Brazil. Arq Cienc Mar 20: 25-32.

GIRALDES BW \& SMYTH DM. 2016. Recognizing Panulirus meripurpuratus sp. nov. (Decapoda: Palinuridae) in Brazil-Systematic and biogeographic overview of Panulirus species in the Atlantic Ocean. Zootaxa 4107: 353-366. http://dx.doi.org/10.11646/zootaxa.4107.3.4.

GONÇALVES AA. 2011. Tecnologia do pescado: ciência, tecnologia, inovação e legislação. $1^{a}$ ed. São Paulo: Atheneu, p. 608.

GOODMAN LA. 1964. Simultaneous confidence intervals for contrast among multinomial populations. Ann Math Stat 35: 716-725. http://dx.doi.org/10.1214/aoms/1177703569.

HOLLANDER M \& WOLFE DA. 1973. Nonparametric Statistical Methods. New York: J Wiley \& Sons, p. 115-120.

IGARASHI MA. 2007. Sinopse da situação atual, perspectivas e condições de cultivo para lagostas Paniluridae. Ciênc Anim Bras 8: 151-166.

IGARASHI MA, SILVA JWB, VIANA MSR \& FILHO AAS. 2000. Ciclo de desenvolvimento e perspectiva para o cultivo da Lagosta, Panulirus sp. Rev Ciênt de Prod Anim 2: 107-118.

IVO CTC. 2000. Caracterização populacional da lagosta Panulirus laevicauda (Latreille), capturada nas regiões Nordeste e Sudeste do Brasil. Arq Cienc Mar 33: 85-92.

IVO CTC \& RIBEIRO-NETO J. 1996a. Estudo comparativo sobre a pesca de lagosta com covo e rede de espera no estado do Ceará. Bol Téc Cient CEPENE 4: 95-134.

IVO CTC \& RIBEIRO-NETO J. 1996b. Estudo Comparativo Sobre a Pesca de Lagostas Com Rede de Espera e Mergulho no
Estado do Rio Grande do Norte. Bol Téc Cient CEPENE 4: 135-172.

IVO CTC, FONTELES-FILHO AA, SILVA AC \& VIEIRA RHSF. 2013. Cadeia produtiva da lagosta nas regiões Norte e Nordeste do Brasil. Fortaleza: Editora RDS, p. 218.

IVO CTC, VASCONCELOS EMS \& MAGALHÃES JAD. 1995. Avaliação dos parâmetros biométricos das lagostas Panulirus argus (Latreille) e Panulirus laevicauda (Latreille), na plataforma continental nordeste/sudeste do Brasil. Bol Téc Cient CEPENE 3: 169-200.

LIMA GFC. 1997. O debate da sustentabilidade na sociedade insustentável. Política \& Trabalho 13: 201-222.

LIMA SAO \& ANDRADE HA. 2017. Variações nas capturas das lagostas vermelha (Panulirus meripurpuratus), verde (Panulirus laevicauda Latreille, 1817) e sapata (Scyllarides brasiliensis Rathbun, 1906) na costa de Pernambuco. Bol Inst Pesca 43: 194-206. http://dx.doi. org/10.20950/1678-2305.2017v43n2p194.

MADRID R \& IZQUIERDO RC. 2013. Lagosta brasileira. Um diamante desvalorizado. Ciênc Hoje 303: 34-38.

MDIC - MINISTÉRIO DA INDÚSTRIA, COMÉRCIO EXTERIOR E SERVIÇOS. 2018. (sem data, on line) Grupos de Produtos: Exportação. Retrieved June 11, 2018, from http://www.mdic.gov.br/index.php/comercio-exterior/ estatisticas-de-comercio-exterior/series-historicas.

MELO GAS. 1999. Manual de identificação dos crustáceos decapoda do litoral brasileiro: Anomura, Thalassinidea, Palinuridea, Astacitea. São Paulo, Plêiade/Fapesp, p. 551.

NENADIC O \& GREENACRE MJ. 2007. Correspondence Analysis in R, with Two and Three Dimensional Graphics: The ca Package. J Statist Software 20: 1-13. http://dx.doi. org/10.18637/jss.v020.i03.

NEVES SDS, CRUZ R, CINTRA IHA \& SILVA KCA. 2013. Impact of lobster size on catches and prediction of commercial spiny lobster landings in Brazil. Crustaceana 86: 12741290. https://doi.org/10.1163/15685403-00003230.

OCEÂNICA. 2020. APA Recifes de Pirangi: proposta de criação de área protegida costeiro-marinha no Rio Grande do Norte. ONG Oceânica, p. 195.

OLIVEIRA PA, VENDEL AL \& CRISPIM MCB. 2009. Caracterização socioeconômica e registro da percepção dos pescados de lagosta das praias do Seixas e Penha, João Pessoa, PB. Bol Inst Pesca 35: 637-646.

OLIVEIRA VS, ANDRADE HA, HAZIN FHV \& VIEIRA AC. 2015. Pesca da lagosta com covos na costa central de Pernambuco: taxas de captura da lagosta e fauna acompanhante. Bol Inst Pesca 41: 373-385. 
POHLERT T. 2016. Calculate Pairwise Multiple Comparisons of Mean Rank Sums. version 4.1. Package of R.

R DEVELOPMENT CORE TEAM. 2009. R: a Language and Environment for Statistical Computing. Vienna: R Foundation for Statistical Computing. ISBN 3-900051-070. http://www.R-project.org.

RODRIGUES RA \& MAIA LP. 2007. Caracterização sócioeconômica das comunidades de pescadores do município de Aquiraz-Ceará. Arq Cienc Mar 40: 16-23.

SALAS S, CHUENPAGDEE R, SEIJO JC \& CHARLES A. 2007. Challenges in the assessment and management of smallscale fisheries in Latin America and the Caribbean. Fish Res 87: 5-16. https://doi.org/10.1016/j.fishres.2007.06.015.

SANTANA JVM, NEVES SS, SARAIVA SZR, ADAMS C \& CRUZ R. 2015. Current management and externalities in lobster fisheries exploitation on the continental shelf of Ceará, Brazil. Arq Cienc Mar 48: 5-18.

SANTANA W, IVO CTC, DIAS-NETO J, DUARTE LFA, PINHEIRO MAA, BOOS H, PINHEIRO AP, ALMEIDA AO, HERNÁEZ P \& COELHO PA. 2016. Avaliação Lagostas-de-espinho (Decapoda: Palinuridae). In: Pinheiro MAA \& Boos H. Livro Vermelho dos Crustáceos do Brasil: Avaliação 2010-2014. Porto Alegre: Sociedade Brasileira de Carcinologia - SBC, p. 268-283. Retrieved June 10, 2018, from http://www. crustacea.org.br/wp-content/themes/crustacea-2014/ img/lv/pdf/livro-vermelho-cap21-avaliacao-daslagostas-de-espinho.pdf.

SANTOS EP \& IVO CTC. 1973. Crescimento e idade da lagosta Panulirus laevicauda (Latreille), em águas costeiras do Estado do Ceará (Brasil). Arq Cienc Mar 13: 19-23.

SANTOS PVC, ALMEIDA-FUNO ICS, PIGA FG, FRANÇA VL, TORRES SA \& MELO CDP. 2011. Perfil socioeconômico de pescadores do município de Raposa, Estado do Maranhão. Rev Bras Eng Pesc 6(1): I-XIV.

SHAPIRO SS \& WILK MB. 1965. An Analysis of Variance Test for Normality (Complete Samples). Biometrika 52: 591611. http://dx.doi.org/10.2307/2333709.

SHORT AD \& KLEIN AHF. 2016. Brazilian Beach Systems. Coastal Research Library 17. Switzerland: Springer, p. 611.

SILVA AP. 2014. Pesca artesanal brasileira. Aspectos conceituais, históricos, institucionais e prospectivos. Boletim de Pesquisa e Desenvolvimento. Palmas: Embrapa Pesca e Aquicultura, p. 32. Retrieved May 10, 2018, from https://ainfo.cnptia.embrapa.br/digital/ bitstream/item/108691/1/bpd3.pdf.

SILVA ELP, WANDERLEY MB \& CONSERVA MS. 2014. Proteção social e território na pesca artesanal do litoral paraibano.
Serv Soc Soc 117: 169-188. http://dx.doi.org/10.1590/ S0101-66282014000100010.

SILVA KCA, BOTELHO KB, CINTRA IHA \& ARAGÃO JAN. 2008. Parâmetros reprodutivos da lagosta vermelha Panulirus argus (Latreille, 1804), na costa norte do Brasil. Bol Téc cient CEPNOR 8: 27-39.

SPARRE P \& VENEMA SC. 1997. Introdução à avaliação de mananciais de peixes tropicais. Parte l: Manual. FAO Documento Técnico sobra as Pescas. No. 306/1, Rev.2. Roma: FAO, p. 404.

STEARNS S. 1976. Life Histoy Tactics: A Review of the Ideas. Q Rev Biol 51: 3-47. https://www.jstor.org/stable/2825234.

TAMANO LTO, ARAUJO DM, LIMA BBC, SILVA FNF \& SILVA J. 2015. Socioeconomia e saúde dos pescadores de Mytella falcata da Lagoa Mundaú, Maceió-AL. Bol Mus Para Emílio Goeldi, sér. Ciências Humanas 10: 699-710. http:// dx.doi.org/10.1590/1981-81222015000300011.

TURSI A, MAIORANO P, SION L \& DO'NGHIA G. 2015. Fishery resources: between ecology and economy. Rend Fis Acc Lincei 26: 73-79. http://dx.doi.org/10.1007/ s12210-014-0372-3.

VASCONCELOS JA \& VASCONCELOS EMS. 1994. Determinação de novos parâmetros biométricos das lagostas Panulirus argus (Latreille) e Panulirus laevicauda capturadas no Litoral do Rio Grande do Norte. Bol Téc Cient CEPENE 2: 51-58.

ZAR JH. 2010. Biostatistical Analysis. 5th ed. Upper Saddle River, N.J.: Prentice-Hall/Pearson, p. 944.

\section{How to cite}

ALENCAR CERD, ARAÚJO PVN, AMORIM LC, LIMA MSP, MENDES LF \& FREIRE FAM. 2021. Artisanal fisheries of native spiny lobster Panulirus meripurpuratus and smoothtail spiny lobster Panulirus laevicauda in the northeast region of Brazil. An Acad Bras Cienc 93: e20190715. DOI 10.1590/0001-3765202120190715.

Manuscript received on June 27, 2019;

accepted for publication on February 27, 2020

\section{CARLOS E.R.D. ALENCAR ${ }^{1,2}$}

https://orcid.org/0000-0003-4231-4326

PAULO V. DO N. ARAÚJO 3

https://orcid.org/0000-0002-0625-0946

\section{LARA C. AMORIM ${ }^{4}$}

https://orcid.org/0000-0002-8092-2771

MAURO S.P. LIMA ${ }^{5}$

https://orcid.org/0000-0002-8574-7183 
LIANA DE F. MENDES ${ }^{4}$

https://orcid.org/0000-0001-5290-9054

\section{FÚLVIO A. DE M. FREIRE ${ }^{2}$}

https://orcid.org/0000-0003-1580-0222

'Laboratório de Crustáceos do Semiárido (LACRUSE),

Universidade Regional do Cariri (URCA), Departamento de

Ciências Biológicas, Centro de Ciências Biológicas e da Saúde, Rua Cel. Antônio Luiz, 1161, Pimenta , 63105-000 Crato, CE, Brazil

${ }^{2}$ Laboratório de Biologia, Ecologia e Evolução de Crustáceos (LABEEC), Departamento de Botânica e Zoologia, Centro de Biociências, Universidade Federal do Rio Grande do Norte (UFRN), Campus

Universitário Lagoa Nova, 59072-970 Natal, RN, Brazil

${ }^{3}$ Instituto Federal de Educação, Ciência e Tecnologia do Rio Grande do Norte (IFRN), Campus Macau, Rua das Margaridas, 300, Conjunto COHAB, 59500-000 Macau, RN, Brazil

${ }^{4}$ Laboratório do Oceano (LOC), Universidade Federal do Rio Grande do Norte (UFRN), Campus Universitário Lagoa Nova, 59072-970 Natal, RN, Brazil

${ }^{5}$ Oceânica - Pesquisa, Educação e Conservação, Rua Maria Joaquina da Conceição, 15, Pirangi do Norte, 59161-485 Parnamirim, RN, Brazil

Correspondence to: Carlos E.R.D. Alencar

E-mail:carlosce2002@gmail.com

\section{Author Contributions}

Carlos Eduardo Alencar: Conceptualization, Methodology, Investigation, Statistical Analysis, Data Curation, Writing Original Draft. Paulo Victor Araújo: Methodology, Investigation, Statistical Analysis, Writing - Original Draft, Writing - Review \& Editing. Lara Amorim: Methodology, Writing - Review. Mauro Lima: Conceptualization, Methodology, Investigation, Writing - Review \& Editing. Liana Mendes: Conceptualization, Methodology, Investigation, Supervision, Project Administration, Writing - Review \& Editing. Fúlvio Freire - Supervision, Writing - Review \& Editing.

\section{(c) BY}

